\title{
Description of immature stages of Ablabesmyia cordeiroi Neubern, 2013 (Diptera: Chironomidae: Tanypodinae)
}

\author{
Fabíola Lima DA SILVA, Galileu Petronilo da Silva DANTAS*, Neusa HAMADA \\ Instituto Nacional de Pesquisas da Amazônia - INPA, Coordenação de Biodiversidade - COBIO, Av. André Araújo 2936, CEP 69067-375, Manaus, Amazonas, Brasil. \\ * Corresponding author: galileu.psd@gmail.com
}

\section{ABSTRACT \\ Abalesmyia cordeiroi Neubern was originally described based on adult males collected in the Amazon region; therefore, females and immatures of this species are unknown. In the present study, the pupal and larval stages of $A$. cordeiro $i$ are described and illustrated. In addition, an amendment to the larval diagnosis of Ablabesmyia is provided. \\ KEYWORDS: aquatic insects, non-biting midges, Pentaneurini, Brazil \\ Descrição dos estágios imaturos de Ablabesmyia cordeiroi Neubern, 2013 (Diptera: Chironomidae: Tanypodinae)}

\section{RESUMO}

Ablabesmyia cordeiroi Neubern foi descrita originalmente com base em machos coletados na regiáo amazônica, portanto, a fêmea e os imaturos desta espécie são desconhecidos. No presente estudo, os estágios de pupa e larva de $A$. cordeiroi são descritos e ilustrados. Além disso, uma emenda à diagnose da larva de Ablabesmyia é fornecida.

PALAVRAS-CHAVE: insetos aquáticos, chironomídeos, Pentaneurini, Brasil

Ablabesmyia Johannsen is the most diverse genus in Tanypodinae, with about 90 species distributed worldwide (Fittkau and Murray 1986; Ashe and O'Connor 2009; Neubern et al. 2013). Although Ablabesmyia is common and diverse in the Neotropical region, in about $50 \%$ of the species the immature stages are unknown, and most of them were described based only on males, which have a conspicuous coloration pattern and complex hypopigial structures. Larvae of the genus are predatory, feeding on smaller chironomid larvae and oligochaetes. They live in a wide variety of aquatic habitats, both lentic and lotic, including at least one species with larva associated with freshwater sponges (Fusari et al. 2012) and one living symbiotically with Unionidae mussels (Roback 1982). Ablabesmyia cordeiroi Neubern, 2013 was described based only on males collected in Amazonia (Neubern et al. 2013). The objectives of this study were to describe the pupal and larval stages of this species. In addition, an amendment to the larval diagnosis of Ablabesmyia is provided.

A larva of $A$. cordeiro $i$ was collected associated with aquatic vegetation using a hand net. In the laboratory, the larva was individually reared in a plastic vial and was fed on Chironominae and Orthocladiinae larvae. For further details on rearing techniques, see Mendes (2002). The emerged adult was kept alive for at least 24 hours to adequately preserve the coloration. It was then fixed in $80 \%$ alcohol, together with the pupal and larval exuviae. The specimen examined was slide-mounted in Euparal following the procedures outlined by Pinder $(1983,1986,1989)$. The terminology follows Sxther (1980). The types of $A$. cordeiroi in the reference collection of the aquatic entomology laboratory (Laboratório de Entomologia Aquática - LEA) of Universidade Federal de São Carlos - UFSCar (São Carlos, São Paulo, Brazil) were examined to certify the identification of the reared specimen. The reared male specimen and its larval and pupal exuviae are deposited in the Invertebrate Collection of Instituto Nacional de Pesquisas da Amazônia - INPA, Manaus, Amazonas, Brazil (INPA.DIP001955).

\section{Taxonomic treatment}

Family: Chironomidae Newman, 1834

Subfamily: Tanypodinae Skuse, 1889

Tribe: Pentaneurini Fittkau, 1962

Genus: Ablabesmyia Johannsen, 1905 
Amended diagnosis. The following addition is provided to the generic diagnosis reviewed by Neubern et al. (2013):

Larva. At least one species has one bifid claw at apex of posterior parapods.

\section{Ablabesmyia cordeiroi Neubern, 2013}

Material examined. Holotype: male, Brazil, Amazonas, Manaus, Cuieiras ZF02, (600'ㄷ' W, $\left.02^{\circ} 35^{\prime} 22^{\prime \prime} S\right)$, 14.vii.2008, C.S.N. Oliveira (LEIA). Paratypes: two males, same data as holotype. Additional material: one male with pupal and larval exuviae, Presidente Figueiredo, Igarapé da Onça, Recanto da Pantera, (02 $\left.00^{\prime} 52^{\prime \prime} S, 60^{\circ} 01^{\prime} 43^{\prime \prime W}\right)$, 10.xii.2012, G.P.S. Dantas (INPA).

Diagnostic characters. Pupa: wing sheath smooth, with brown pigmentation restricted to the edges and some veins; thoracic horn lumen with hexagonal pattern, spines present on the base, aeropyle membranous with a simple tube; genital sac apex rounded beyond the insertion of the second macroseta of the anal lobe. Larva: postoccipital margin without projections; basal segment of maxillary palp subdivided into two parts; ligula with anterior row of teeth strongly concave; posterior parapods with one short, bifid claw; all claws of the posterior parapods light yellow.

Pupa $(\mathrm{n}=1)$.

Total length $=2.95 \mathrm{~mm}$ (abdomen of male).

Coloration. Thoracic horn dark-brown (Figure 1A); wing sheath whitish, with brown pigmentation restricted to the edges and some veins as in Figure 1B. Abdomen light brown, without distinct spots (Figure 1C).

Cephalothorax. Frontal apotome apically truncated. Wing sheath smooth (Figure 1B), $1088 \mu \mathrm{m}$ long, $370 \mu \mathrm{m}$ maximum width. Thoracic horn (Figure 1A) $431 \mu \mathrm{m}$ long, $198 \mu \mathrm{m}$ maximum width, lumen with hexagonal pattern, spines present on the base, aeropyle membranous, $25 \mu \mathrm{m}$ long, 38 $\mu \mathrm{m}$ wide, with a simple tube, outer membrane with spines on the dorsal margin; thoracic comb with 16 teeth.

Abdomen (Figure 1C). TI-VII with large field of shagreen, composed of small spines arranged in transverse rows; TVIII with large field of shagreen formed by small scattered spines; anal lobe with shagreen. TI with a distinct elongated scar, 86 $\mu \mathrm{m}$ long. Segment VII with $4 \mathrm{LS}$ setae. Segment VIII with 5 lateral filaments. Anal lobe as in Figure 1D, $400 \mu \mathrm{m}$ long, 340 $\mu \mathrm{m}$ wide at base, spiniform at apex; two lateral macrosetae, with adhesive sheath; outer margins with four spines, inner margin without spines. Genital sac $254 \mu \mathrm{m}$ long, $235 \mu \mathrm{m}$ wide at base, apex beyond the insertion of the second macroseta of the anal lobe. GS/AL 0.63 .

\section{Larva $(\mathrm{n}=1)$.}

Coloration. Head capsule yellow; post-occipital margin brown; antenna and maxillary palp yellowish; mandible yellow with brown apex; ligula brown at apex. Abdomen yellowish;

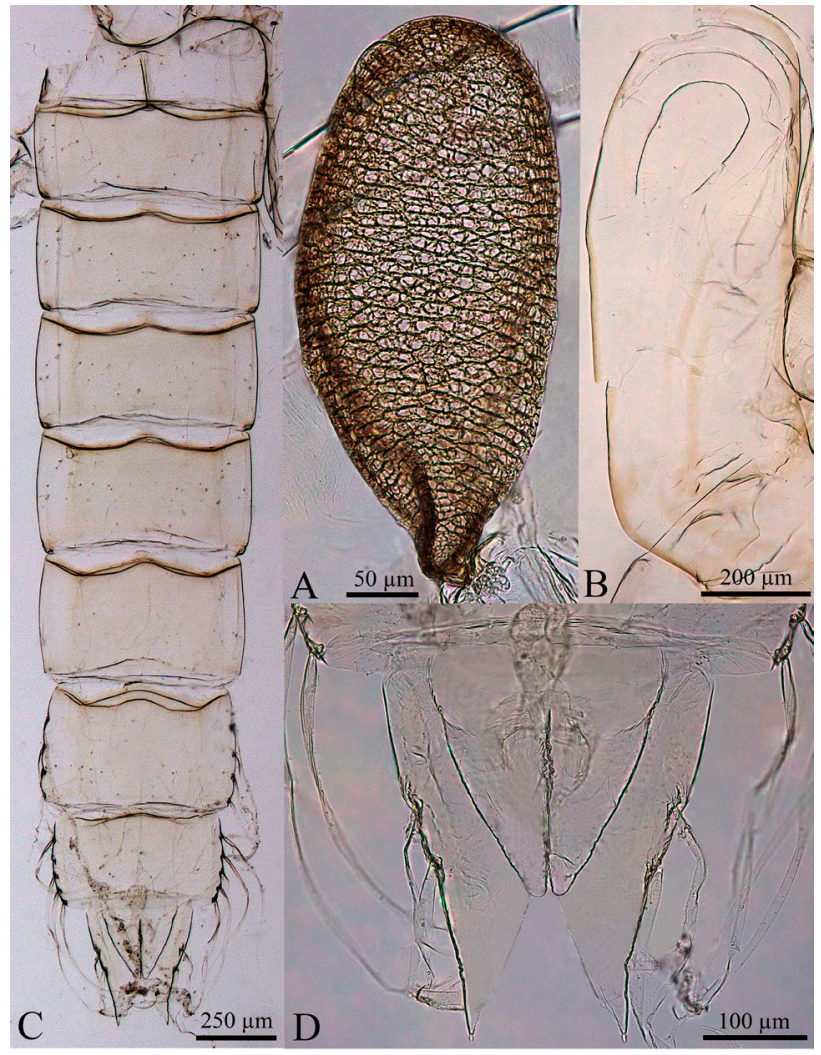

Figure 1. Ablabesmyia cordeiroi Neubern, pupa. (A) thoracic horn; (B) wing sheath; (C) abdomen; (D) anal lobe. This figure is in color in the electronic version.

procercus and anal setae yellowish; all claws of posterior parapods light yellow.

Head (Figure 2A). Head capsule oval in shape; total length $715 \mu \mathrm{m}, 473 \mu \mathrm{m}$ wide, cephalic index 0.66. Chaetotaxy as in Figure 2A. Ventrally, VP closer to S10 than to S9, located posterior to S9, mesial to $S 10$. Ventral scars slender, $60 \mu \mathrm{m}$ long, distant from each other by $90 \mu \mathrm{m}$, distant from the occipital margin by $76 \mu \mathrm{m}$. Postoccipital margin without projections (Figure $2 \mathrm{~A}$ ).

Antenna. $\mathrm{A}_{1} 350 \mu \mathrm{m}$ long, $19 \mu \mathrm{m}$ maximum width, ring organ placed $205 \mu \mathrm{m}$ from base.

Maxilla. Basal segment of maxillary palp (Figure 2B) subdivided into 2 parts, basal $\left(\mathrm{P}_{1}\right) 36 \mu \mathrm{m}$ long and 12 wide, apical $\left(\mathrm{P}_{2}\right) 37 \mu \mathrm{m}$ long and $10 \mu \mathrm{m}$ wide; ring organ placed $30 \mu \mathrm{m}$ from base; palpiger small, $16 \mu \mathrm{m}$ long and $14 \mu \mathrm{m}$ wide. $A_{1} / P_{1} 9.72$.

Mandible (Figures 2C-D). Gradually curved and tapered towards apex, $144 \mu \mathrm{m}$ long; with three lateral setae, ring organ placed $30 \mu \mathrm{m}$ from base. Apical tooth $47 \mu \mathrm{m}$ long, mola projection large, blunt-ended and directed apically; inner tooth large, bluntly rounded (Figure $2 \mathrm{C}$ ), partly overlying seta subdentalis. Seta subdentalis $41 \mu \mathrm{m}$ long. $\mathrm{A}_{1} / \mathrm{MD} 2.43$. 


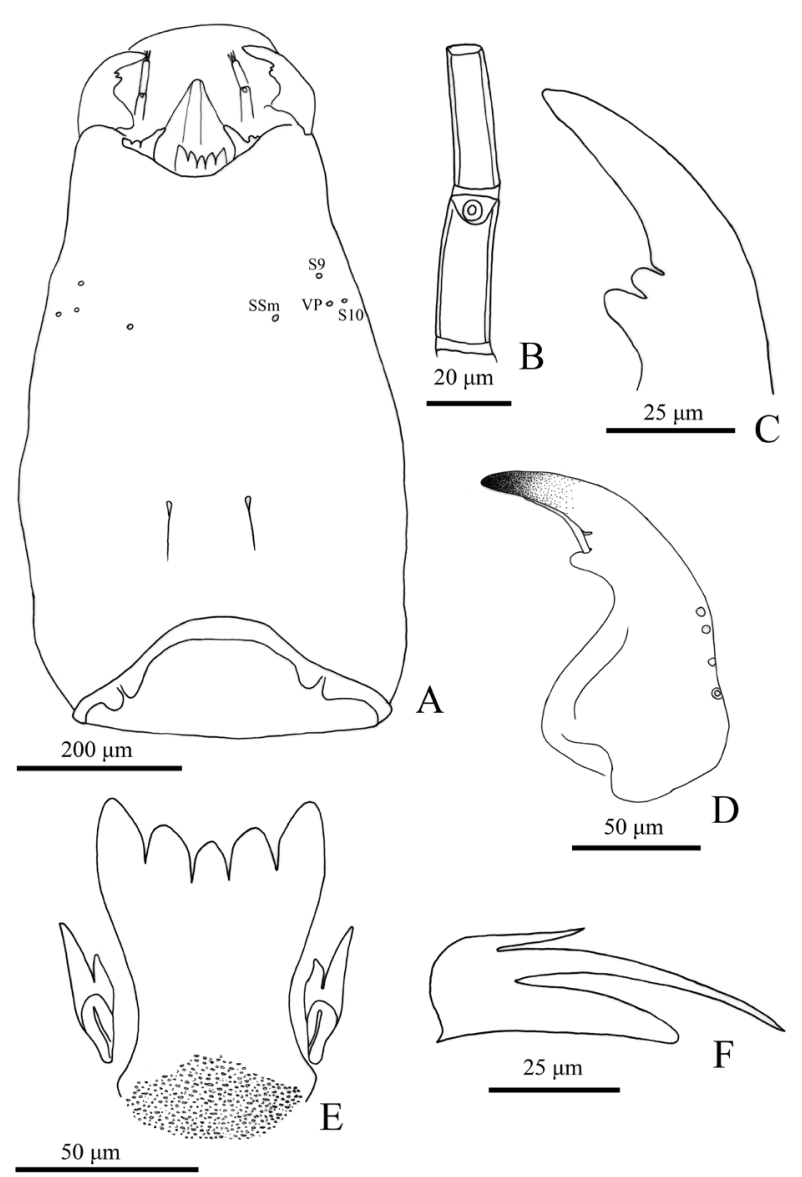

Figure 2. Ablabesmyia cordeiroi Neubern, larva. (A) head; (B) maxillary palp; (C) apex of mandible; (D) mandible; (E) ligula and paraligula; (F) bifid claw of posterior parapod.

Mentum and $M$ appendage. Dorsomental teeth reduced, $\mathrm{M}$ appendage rounded apically; pseudoradula $140 \mu \mathrm{m}$ long, $14 \mu \mathrm{m}$ wide, uniformly granulated. Labial vesicles $36 \mu \mathrm{m}$ long, oval-shaped.

Hypopharyngeal complex (Figure 2E). Ligula $91 \mu \mathrm{m}$ long, $60 \mu \mathrm{m}$ wide at apex, $41 \mu \mathrm{m}$ at the middle and $53 \mu \mathrm{m}$ at the base, with five teeth, anterior row of teeth strongly concave; granulated at base. Paraligula bifid and robust, $37 \mu \mathrm{m}$ long and $11 \mu \mathrm{m}$ wide. Pecten hypopharyngis with 13 teeth.

Body. Without fringe of swim-setae. Anterior parapods with simple claws. Procercus $110 \mu \mathrm{m}$ long, $32 \mu \mathrm{m}$ wide at base, with seven anal setae, $588 \mu \mathrm{m}$ long. Supra-anal setae $273 \mu \mathrm{m}$ long. Sub-basal setae of posterior parapod $200 \mu \mathrm{m}$ long. Anal tubules not measurable. Posterior parapods with hooklets and 13 simple claws and one shorter claw wide at base and bifid at apex (Figure 2F).

\section{Remarks on systematics}

The pupa of $A$. cordeiroi would key to $A$. communiba Neubern in Neubern et al. (2013), however, in $A$. communiba the genital sac is $300-350 \mu \mathrm{m}$ long and the veins of the wing sheath are complete, while in A. cordeiroi the genital sac is about 250 $\mu \mathrm{m}$ long and the veins of the wing sheath are incomplete. In contrast, the larva of $A$. cordeiro $i$ does not key to any couplet in Neubern et al. (2013), due to its unique combination of characters, mainly the bifid claw on the posterior parapods (Figure 2F). Considering an initial hypothesis of primary homology, this peculiar character which does not appear in any other known larva of Ablabesmyia, should be treated as a plesiomorphy, since it also occurs in all species of Labrundinia Fittkau and Denopelopia Roback \& Rutter, which are genera that were recently recovered as the sister group of Ablabesmyia by Krosch et al. (2017).

\section{Notes on biology}

The larva of $A$. cordeiro $i$ was collected associated with aquatic vegetation in a backwater area of a black-water stream. The species is known only from Amazonas state, Brazil.

\section{ACKNOWLEDGMENTS}

FLS received a PIBIC/PAIC scholarship from Conselho Nacional de Desenvolvimento Científico e Tecnológico CNPq (Brazil), GPSD received a scholarship from Programa PCI-INPA (Ministério de Ciência, Tecnologia, Inovação e Comunicaçóes - MCTIC/CNPq), and NH is a CNPq reserach fellow (process \# 307849/2014-7). INPA and CNPq projects (Sistemática Integrada de Insetos Aquáticos na América do Sul) provided financial resources for fieldwork. Thanks are due to Dr. Philip M. Fearnside for his comments on an early version of this manuscript. We are indebted to Dr. Livia M. Fusari (Universidade Federal de São Carlos UFSCar), who allowed access to the types of $A$. corderoi.

\section{REFERENCES}

Ashe, P.; O'Connor, J.P. 2009. A world catalogue of Chironomidae (Diptera), Part 1. Buchonomyiinae, Chilenomyiinae, Podonominae, Aphroteniinae, Tanypodinae, Usamboramyiinae, Diamesinae, Prodiamesinae and Telmatogetoninae. 1st ed. The National Museum of Ireland, Ireland, 455p.

Fittkau, E.J.; Murray, D.A. 1986. The pupae of Tanypodinae (Diptera: Chironomidae) of the Holarctic region - Keys and diagnoses. In: Wiederholm, T. (Ed.), Chironomidae of the Holarctic region - Keys and diagnoses. Part 2. Pupae. Entomologica scandinavica, Supplement. 28: 31-113.

Fusari, L.M.; Oliveira, C.S.N.; Hamada, N.; Roque, F.O. 2012. New species of Ablabesmyia Johannsen from the Neotropical region: first report of a sponge-dwelling Tanypodinae. Zootaxa, 3239: 43-50.

Krosch, M.N.; Cranston, P.S.; Bryant, L.M.; Strutt, F.; McCluen, S.R. 2017. Towards a dated molecular phylogeny of the Tanypodinae (Chironomidae, Diptera). Invertebrate Systematics, 31: 302-316. 
Mendes, H.F. 2002. Rearing Tanypodinae, Telmatogetoninae and Orthocladiinae in Brazil, an empirical approach. Chironomus Newsletter on Chironomidae Research, 15: 29-32.

Neubern, C.S.O.; Silva, M.A.N.; Gessner, A.A.F. 2013. Neotropical Ablabesmyia Johannsen (Diptera: Chironomidae, Tanypodinae) - Part I. Zootaxa, 3733: 001-123.

Pinder, L.C.V. 1983. The larvae of Chironomidae (Diptera) of the Holarctic region - Introduction. In: Wiederholm, T. (Ed.), Chironomidae of the Holarctic region - Keys and diagnoses. Part 1. Larvae. Entomologica Scandinavica Supplement, Lund, Sweden, 19: 7-10.

Pinder, L.C.V. 1986. The pupae of Chironomidae (Diptera) of the Holarctic region - Introduction. In: Wiederholm, T. (Ed.), Chironomidae of the Holarctic region - Keys and diagnoses. Part 2. Pupae. Entomologica Scandinavica Supplement, Lund, Sweden, 28: 5-7.
Pinder, L.C.V. 1989. The adults of Chironomidae (Diptera) of the Holarctic region - Introduction. In: Wiederholm, T. (Ed.), Chironomidae of the Holarctic region - Keys and diagnoses. Part 3. Adults male. Entomologica Scandinavica Supplement, Lund, Sweden, 34: 5-9.

Roback, S.S. 1982. Identity of Ablabesmyia sp., Roback, Bereza and Vidrine (1980) (Diptera: Chironomidae). Entomological News, 93: 13-15.

Sæther, O.A. 1980. Glossary of chironomid morphology terminology (Diptera: Chironomidae). Entomologica Scandinavica Supplement, 14: $1-51$.

RECEIVED: $28 / 03 / 2018$

ACCEPTED: 20/09/2018

ASSOCIATE EDITOR: Bruno Spacek Godoy 